\title{
The RITE Assay: Identifying Effectors that Target the Transcription Machinery Using Phage Display Technology
}

BioTechniques 30:380-386 (February 2001)

\author{
Joan M. Mazzarelli and \\ Robert P. Ricciardi \\ University of Pennsylvania, \\ Philadelphia, PA, USA
}

\section{INTRODUCTION}

The greatest challenge to follow the human genome project will be to ascribe functions to the plethora of proteins defined by open reading frames (ORFs). In the field of transcriptional regulation, many recombinant proteins that affect gene expression (effectors) have been identified empirically by testing their abilities to activate or repress transcription. More recently, the components of the general transcription machinery have been elucidated and shown to interact with specific effectors $(2,7)$. To accelerate the identification of transcriptional effectors, we have developed an approach called the reverse identification of transcriptional effectors (RITE). The RITE assay is unlike typical approaches in which the effectors are known and then tested for their abilities to bind specific components of the transcription machinery. In the RITE assay, the effectors are unknown and are identified by their abilities to bind a particular component of the transcription machinery. Using the RITE assay, we have asked what peptide sequences expressed from a phage display cDNA library (15) are capable of interacting with a specific com ponent of the transcription machinery, in this case, hTAF $_{\text {II }} 135(9-11,17)$.

It is important to point out that the RITE assay, which depends simply on direct protein-protein interactions, differs from the well-known yeast two-hybrid screen (3), which relies on transcriptional activity as a measure of protein-protein interactions. In the yeast two-hybrid screen, the target protein (bait) fused to a DNA binding domain, which recognizes a site upstream of the reporter gene, stimulates transcription upon binding a cDNA-encoded protein (prey) fused to an activation domain. In many cases, the target protein, particularly one that has a function in transcription, is able to activate transcription of the reporter gene in the absence of a cDNA-encoded protein, making the yeast two-hybrid screen unusable (14). Indeed, in the absence of prey, regions of $\mathrm{hTAF}_{\mathrm{II}} 135$, our target in the RITE assay, activate transcription when fused to a DNA binding domain in the yeast two-hybrid screen (16).

Here, we demonstrate the utility of the RITE assay to identify effectors that interact with a component of the transcription machinery. Moreover, we discovered through the RITE assay that effectors may contain similar motifs that target distinct surfaces of the transcription machinery.

\section{MATERIALS AND METHODS}

\section{The RITE Assay}

The procedure for the RITE assay is depicted in Figure 1. A human placenta cDNA phage display library (Clontech Laboratories, Palo Alto, CA, USA) was screened for effectors using a C-terminal portion of hTAF ${ }_{\text {II }} 135$ as the target. Phagemid cDNAs were expressed as $\mathrm{N}$-terminal fusions to the phage coat protein $\mathrm{pIII}$. 


\section{Expression Plasmids}

To create the $\mathrm{hTAF}_{\mathrm{II}} 135$ target, the C-terminal 578 amino acids of $\mathrm{hTAF}_{\text {II }} 135$ were fused to the $\mathrm{N}$ terminus of the biotinylated carboxylase carrier protein (BCCP). The BCCP portion is biotinylated on a specific residue allowing the fusion protein to be coupled to streptavidin agarose beads, creating an immobilized target. The plasmid pXa-1 578R, encoding the BCCP$\mathrm{hTAF}_{\mathrm{II}} 135 \mathrm{C}$-terminal fusion, was generated by subcloning a BamHI/NotI fragment from pET21d578R (10) into pXa-1 (Promega, Madison, WI, USA). Constructs pTM1RAR $\alpha$ and pTM $1 \Delta \mathrm{N}$ $91 \mathrm{RAR} \alpha$ were generated by PCR cloning using pSG5RAR $\alpha$ (12) as the DNA template. The plasmids pTM1C/ $\mathrm{EBP} \alpha, \quad \mathrm{pTM} 1 \Delta \mathrm{N} 96 \mathrm{C} / \mathrm{EBP} \alpha$, and

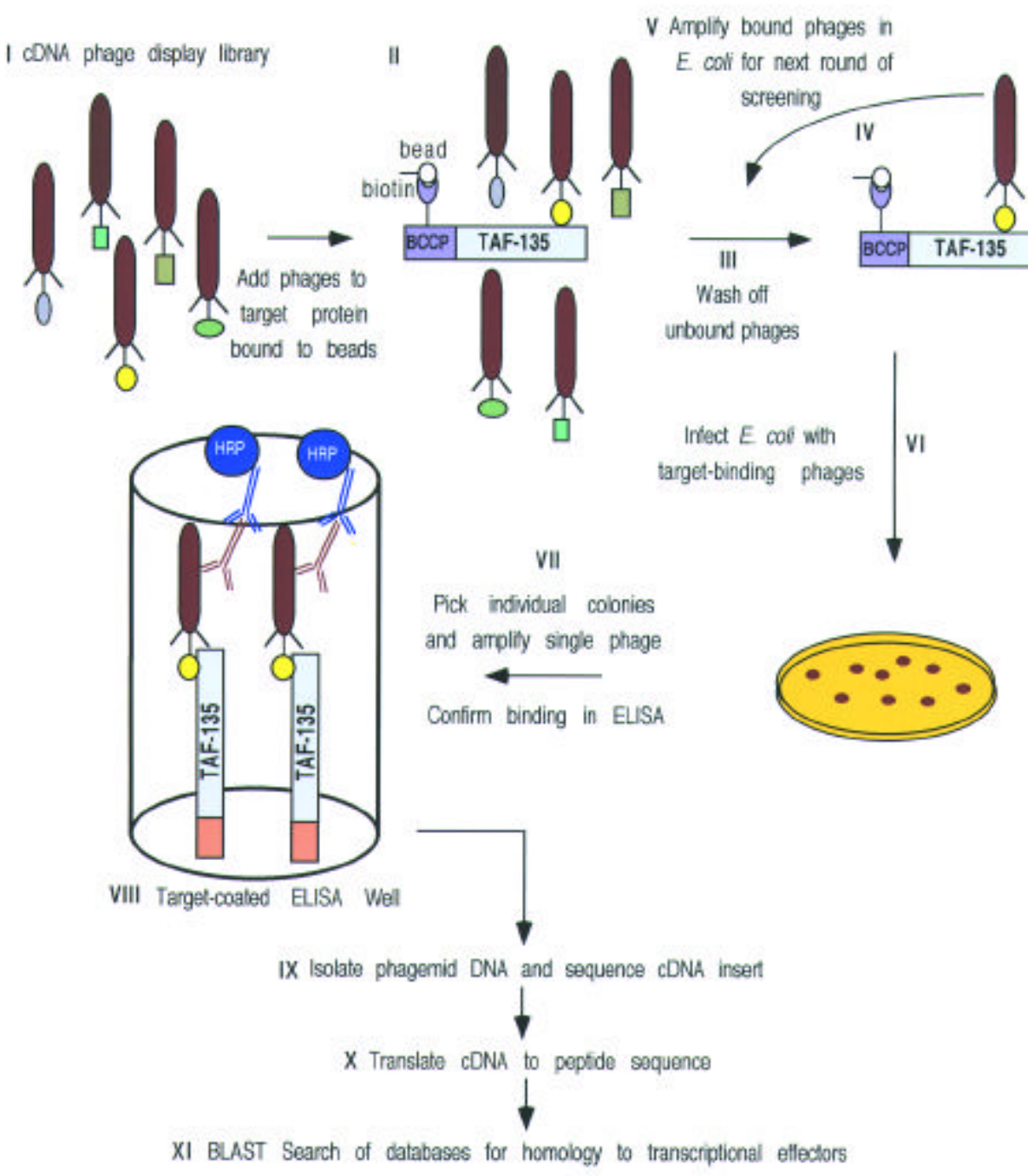

Figure 1. The RITE assay. The cDNA phage display library ( $10^{10}$ phage representing $10^{6}$ independent clones and an insert size range of 60-660) (I) was added to the beads coupled with BCCP-hTAF ${ }_{\text {II }} 135$ fusion protein (about $1 \mu \mathrm{g}$ ) (II) and allowed to bind at $37^{\circ} \mathrm{C}$ for $1 \mathrm{~h}$ in binding buffer (PBS containing $0.05 \%$ Tween ${ }^{\circledR} 20$ and $1 \%$ BSA). After washing the beads in PBS with $0.05 \%$ Tween 20 (III), the retained phage (IV) were amplified by infecting log phase XL-1 Blue cells at $37^{\circ} \mathrm{C}$ for $30 \mathrm{~min}(\mathrm{~V})$. For the amplification, the infected XL-1 Blue cells were collected, grown at $37^{\circ} \mathrm{C}$ for $1 \mathrm{~h}$ in $2 \times$ yeast tryptone (YT)/glucose, following which helper phage were added and growth was continued for $1 \mathrm{~h}$ at $37^{\circ} \mathrm{C}$ in the presence of ampicillin. The infected cells were collected, resuspended in $2 \times \mathrm{YT}$ containing ampicillin and kanamycin, and grown overnight at $37^{\circ} \mathrm{C}$. Amplified phage were purified from the medium by polyethylene glycol precipitation and subjected to two additional rounds of screening with the BCCP-hTAF 135 fusion protein (IV). Retained phage from the final screen were allowed to infect XL-1 Blue cells, which were then plated on $2 \times$ YT/ampicillin plates (VI). Fifty colonies containing phagemids were picked, and individual phage were amplified (VII) and added to ELISA wells coated with a glutathione S-transferase-hTAF 135 C-terminal fusion (GST-hTAF ${ }_{I I} 135$ ) and allowed to bind for $2 \mathrm{~h}$ (VIII). After washing the wells, phage that specifically recognized the $\mathrm{C}$-terminal $\mathrm{hTAF}_{\mathrm{II}} 135$ portion of the fusion were retained. Wells containing the positive-interacting phage were identified by the blue color in an ELISA assay using antibody against the phage coat protein $\mathrm{pVIII}$ followed by a horseradish peroxidase (HRP)-conjugated secondary antibody (VIII). Phagemid DNAs from phage that were positive in the ELISA were isolated, and the cDNA inserts were sequenced (IX). When translated (X), the coding region of the largest cDNA insert (RITE-1 peptide) was analyzed by a BLAST search (XI) and shown to have homology to known transcriptional effectors. 
pTM1 $\Delta 70-200 \mathrm{C} / \mathrm{EBP} \alpha$ were created using either $\mathrm{pSG} 5 \mathrm{C} / \mathrm{EBP} \alpha$ or pcDNA $\triangle 70-200 \mathrm{C} / \mathrm{EBP} \alpha$ (13) as DNA templates. The plasmids pSG5PML$\operatorname{RAR} \alpha(5)$ and $\mathrm{pBSK} \mathrm{RXR}^{+} \alpha$ (8) have been described elsewhere.

\section{Purification of Fusion Proteins and Binding Assays}

Expression of the BCCP-hTAF ${ }_{\text {II }} 135$ $\mathrm{C}$-terminal fusion was induced in the strain JM109 in the presence of $2 \mu \mathrm{M}$ biotin. The cells were lysed, and the cleared supernatant was added to TetraLink $^{\mathrm{TM}}$ Tetrameric Avidin Resin (Promega) and incubated at $4^{\circ} \mathrm{C}$ for $4 \mathrm{~h}$. The resin was then washed in TBS-E and kept at $4{ }^{\circ} \mathrm{C}$ until used in the RITE assay. Purification of GST-hTAF ${ }_{\text {II }} 135$ and the binding to radiolabeled proteins were as described (10) with the excep- tion that the binding and washing buffers utilized in the assay are as described in Figure 1. Labeled proteins were synthesized from DNA templates by in vitro transcription/translation (Coupled TNT System; Promega).

\section{Transfections}

COS cells were transfected by calcium phosphate precipitation, and the total amount of plasmid DNA used in each transfection was normalized by the addition of pAT6 empty vector. Cell extracts were assayed after $48 \mathrm{~h}$ for reporter activity. In each assay, the luciferase activity was normalized based on protein concentration (Bio-Rad Laboratories, Hercules, CA, USA). The cytomegalovirus (CMV) expression vectors, pAT6 and pAT6-hTAF ${ }_{\text {II }} 135$ (372-1083) (11), have been described.

\section{RESULTS AND DISCUSSION}

In the RITE assay depicted in Figure 1 , the $\mathrm{C}$ terminus of $\mathrm{hTAF}_{\mathrm{II}} 135$ was used as the target protein for binding to phage displaying peptide sequences from a human placenta cDNA library. The placenta library was comprised of $10^{6}$ independent phage. Fifty phage obtained from repeated rounds of screening against the biotinylated-hTAF ${ }_{\text {II }} 135$ fusion protein were examined for their interaction with the GST-hTAF ${ }_{\text {II }} 135 \mathrm{fu}$ sion protein. The utilization of two different fusion tags in the screening ensures specific selection of phage that target the hTAF 135 moiety (Figure 1). The cDNA inserts of seven interacting phage were sequenced. Since the human peptides are expressed as fusions to the phage coat protein $\mathrm{pIII}$ and the cDNAs encoding the peptides reside within

RITE-1 peptide 1 HASAGVSSPLSSHIEHSPHIQSCPGEPREGTLLSGPSPPDLPEIDLPVSCCPSGT 55

RITE-1 peptide

RAR alpha

RITE-1 peptide

C/EBP alpha

RITE-1 peptide

XDLL1

RITE-1 peptide

DSXM

RITE-1 peptide

ELL2

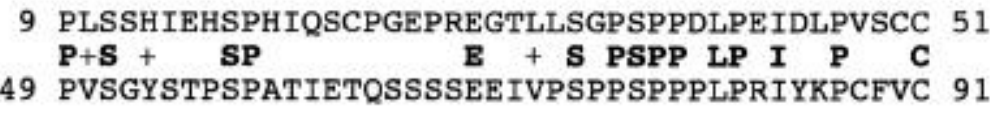

$\begin{array}{lllll}9 & \text { PLSSHIEHSPHIQSCP--GEPREGTLLSGPSPPDLPE } & 43 \\ \text { P+SSH++ PH S } & \text { G PR } & \text { P+ PP } & \text { PE } & \\ 14 & \text { PMSSHLQSPPHAPSSAAFGFPRGAGPPKPPAPPAAPE } & 50\end{array}$

9 PLSSHIEHSPHIQSC 23
P SH +HSP++QSC
76 PYMSHSQHSPYLQSC 90

12 SHIEHSPHIQSCPGEPREGTLLSGPSPPDLP 42

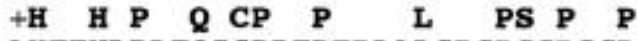

439 AHFTHLPLTQICPPTPEPLALSRSPSSPGP 469

Figure 2. The novel RITE-1 peptide has restricted homology to known transcriptional effectors. A BLAST homology search showing that the RITE-1 peptide, which interacts with the $\mathrm{C}$ terminus of $\mathrm{hTAF}_{\mathrm{II}} 135$, has regions of limited homology to five different transcriptional effectors (see text for details). Identical amino acids are in bold, and those similar in character are denoted by a plus sign. 
phage virions, there is a genotypic linkage between the displayed sequence and the cDNA encoding the sequence (15). The longest cDNA insert from a phage, which bound the hTAF $\mathrm{II}_{1} 135$ target, was shown to encode a novel 55 amino acid sequence, referred to as the RITE-1 peptide (Figure 2, top line).

A basic alignment search tool (BLAST) homology search (1) revealed that the RITE-1 peptide has regions in which the identity and positions of particular residues appear to be conserved in five different transcriptional effectors: retinoic acid receptor alpha (RAR $\alpha)$, CCAAT/enhancer binding protein alpha (C/EBP $\alpha)$, Xenopus homeobox protein distal-less 1 (XDLL1), Drosophila doublesex protein (DSXM), and RNA polymerase II elongation factor (ELL2) (Figure 2). RAR $\alpha$ and $\mathrm{C} / \mathrm{EBP} \alpha$ are two well-characterized transcriptional activators. Interestingly, homology to the RITE peptide- 1 is within the N-terminal activation domains of both RAR $\alpha$ (12) and $\mathrm{C} / \mathrm{EBP} \alpha(13)$, suggesting that these regions likely contact the transcription initiation complex through $\mathrm{hTAF}_{\mathrm{II}} 135$.

To test for a possible interaction between RAR $\alpha$ and $\mathrm{hTAF}_{\mathrm{II}} 135$, we used the GST-hTAF ${ }_{\text {II }} 135$ fusion protein (Figure 1) and radiolabeled RAR $\alpha$ proteins. As shown in Figure 3A, RAR $\alpha$ exhibited strong binding to the GST-

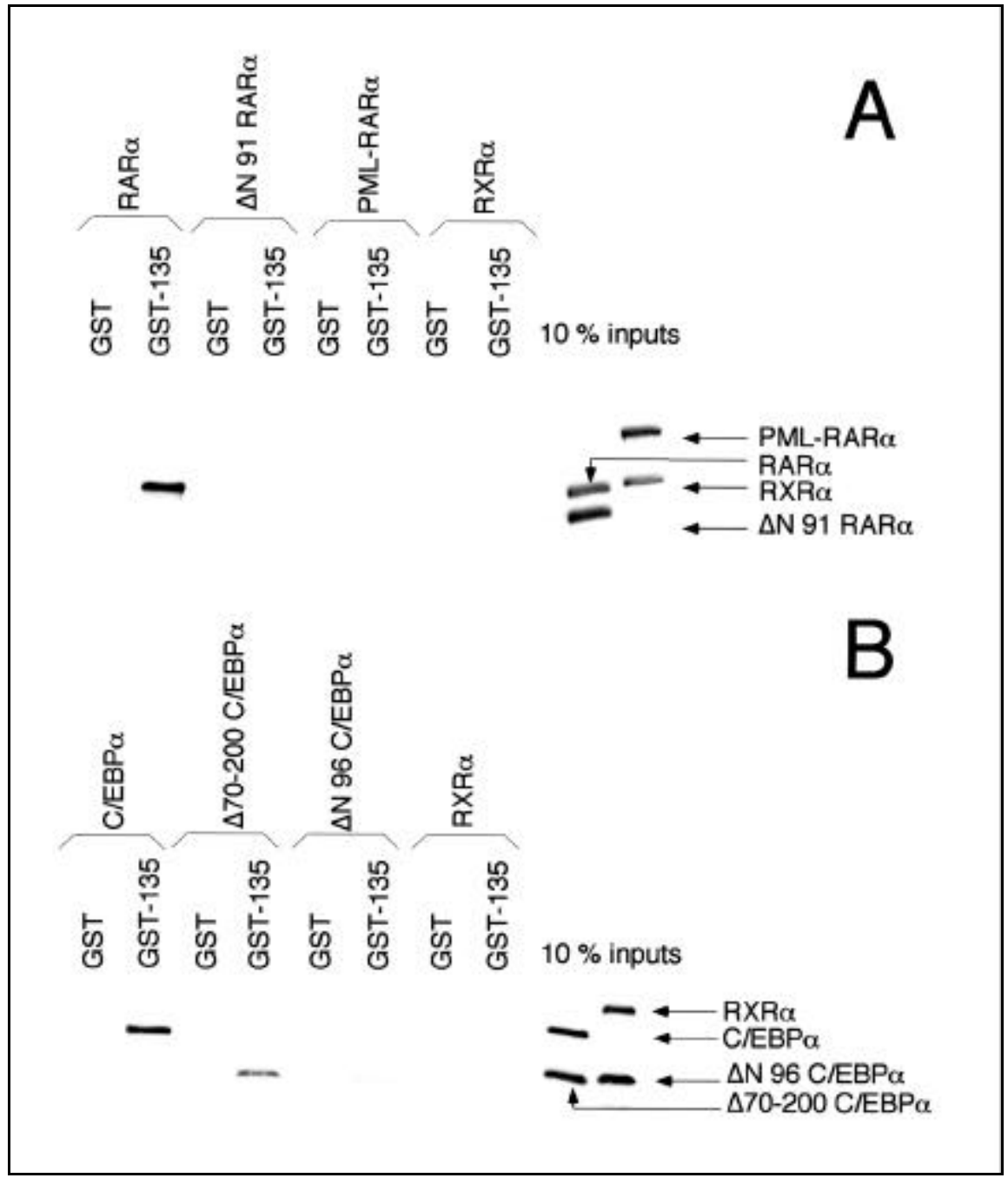

Figure 3. RAR $\alpha$ and $C / E B P \alpha$ interact with the $C$ terminus of hTAF $_{\text {II }}{ }^{135}$. (A) A GST-hTAF ${ }_{\text {II }} 135 \mathrm{C}$ terminal fusion binds to labeled RAR $\alpha$, but not to $\triangle N 91 \mathrm{RAR} \alpha$, which lacks the region of homology to the RITE-1 peptide, nor to PML-RAR or RXR $\alpha$. (B) A GST-hTAF ${ }_{\text {II }} 135$ C-terminal fusion binds to labeled $\mathrm{C} / \mathrm{EBP} \alpha$ and $\Delta 70-200 \mathrm{C} / \mathrm{EBP} \alpha$ but not to $\Delta \mathrm{N} 96 \mathrm{C} / \mathrm{EBP} \alpha$, which lacks the region of homology to the RITE-1 peptide, nor to RXR木. Ten percent of the input counts for each labeled protein are indicated. 
hTAF $_{\mathrm{II}} 135 \mathrm{C}$-terminal fusion protein. Binding specificity was demonstrated by the inability of a different receptor, the retinoid $\mathrm{X}$ receptor alpha $(\mathrm{RXR} \alpha)$, to bind the $\mathrm{hTAF}_{\mathrm{II}} 135$ fusion protein. We then tested a mutant RAR $\alpha$ protein $(\Delta \mathrm{N} 91 \mathrm{RAR} \alpha)$, in which 91 amino acids were deleted from the $\mathrm{N}$ terminus, the region containing homology to the RITE-1 peptide. Indeed, $\Delta \mathrm{N} 91 \mathrm{RAR} \alpha$ proved to be incapable of binding $\mathrm{hTAF}_{\mathrm{II}} 135$. In promyelocytic leukemia (PML), a chromosomal translocation disrupts the domain of RAR $\alpha$, which appears to interact with $\mathrm{hTAF}_{\mathrm{II}} 135$, creating the fusion protein PML-RAR $\alpha$

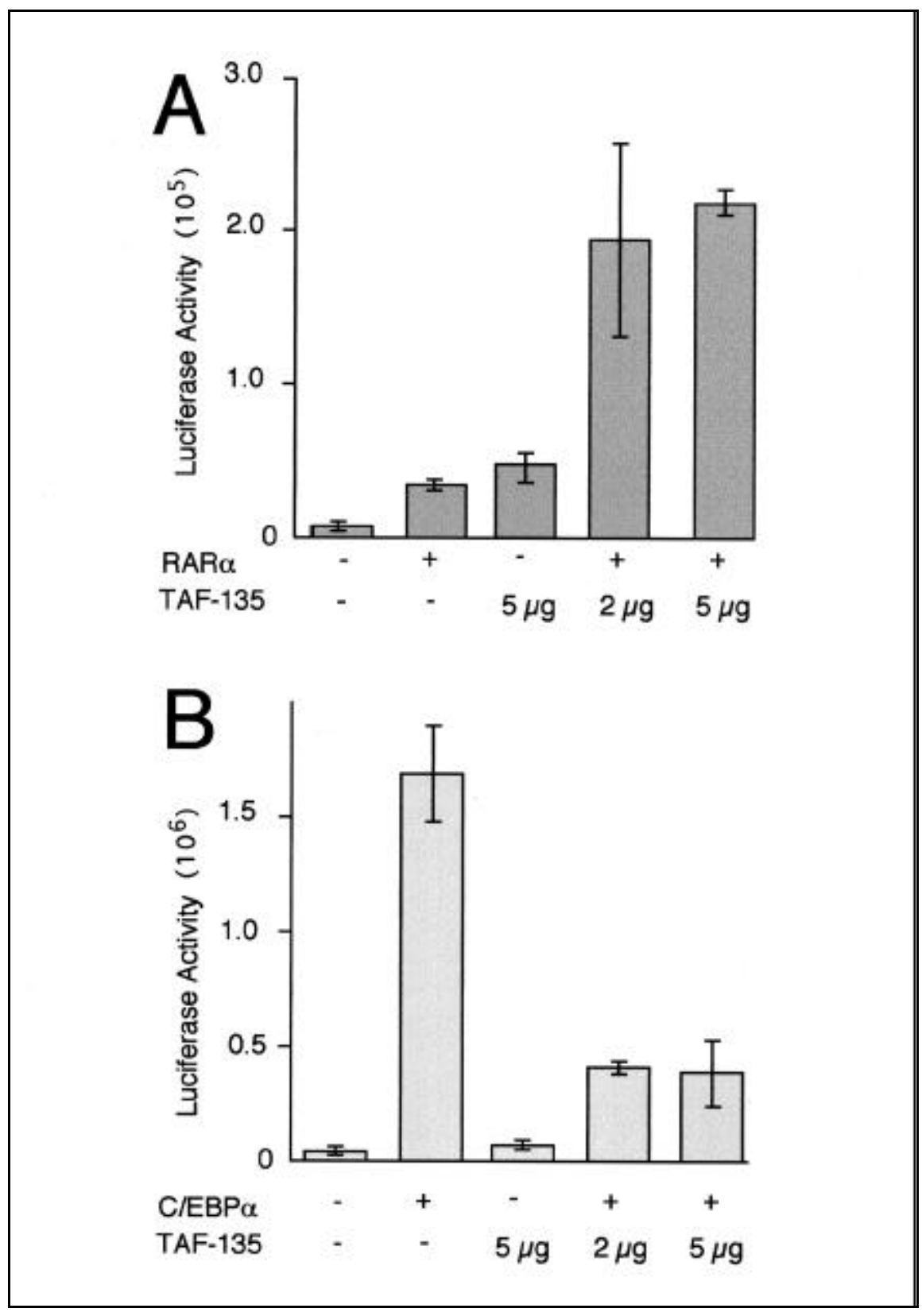

Figure 4. Expression of hTAF 135 affects transcription mediated by $R A R \alpha$ and $C / E B P \alpha$. (A) RAR $\alpha$ expression plasmid $(2 \mu \mathrm{g}), \mathrm{RAR} \beta 2$ promoter luciferase reporter plasmid $(5 \mu \mathrm{g})$, and 2 or $5 \mu \mathrm{g}$ of the hTAF 135 expression vector [hTAF 135 (372-1083)] were cotransfected into COS cells in the presence of retinoic acid $(10 \mu \mathrm{M})$. (B) C/EBP $\alpha$ expression vector $(2 \mu \mathrm{g})$, a luciferase reporter plasmid driven by the obese gene promoter (pObLuc-159) containing a C/EBP $\alpha$ binding site and the $\mathrm{hTAF}_{\mathrm{II}} 135 \mathrm{ex}-$ pression vector were cotransfected into COS cells. Luciferase activities were measured after $48 \mathrm{~h}$. Results represent multiple experiments performed in duplicate.
(5). As shown in Figure 3A, PML$\mathrm{RAR} \alpha$ also failed to bind $\mathrm{hTAF}_{\mathrm{II}} 135$. These findings were confirmed by coimmunoprecipitation experiments. A hemagluttinin (HA)-tagged full-length hTAF $_{\text {II }} 135$ protein was mixed with either radiolabeled RAR $\alpha, \Delta \mathrm{N} 91 \mathrm{RAR} \alpha$, PML-RAR $\alpha$ or RXR $\alpha$. Only RAR $\alpha$ was co-immunoprecipitated with hTAF $_{\text {II }} 135$ using the antibody specific for the HA epitope (not shown).

We then investigated whether $\mathrm{C} / \mathrm{EBP} \alpha$ and $\mathrm{hTAF}_{\mathrm{II}} 135$ were able to associate. As shown in Figure 3B, C/EBP $\alpha$ does bind to GST-hTAF $\mathrm{II}_{135}$. However, when the N-terminal 96 amino acid coding region of $\mathrm{C} / \mathrm{EBP} \alpha$, containing the region of homology to the RITE-1 peptide, was deleted $(\Delta \mathrm{N}$ $96 \mathrm{C} / \mathrm{EBP} \alpha$ ), binding to $\mathrm{hTAF}_{\mathrm{II}} 135$ was dramatically reduced. By contrast, $\Delta 70-200 \mathrm{C} / \mathrm{EBP} \alpha$, which retains the region of homology to the RITE-1 peptide, was still able to bind $\mathrm{hTAF}_{\mathrm{II}} 135$. Again, binding specificity was demonstrated by the inability of $\operatorname{RXR} \alpha$ to bind to hTAF $\mathrm{II}^{135}$.

It was important to ascertain whether the hTAF ${ }_{I I} 135-R A R \alpha$ interaction affected in vivo promoter activity. Transcription from a reporter construct, pRAR $\beta 2$ Luc (4) containing a RAR $\alpha$ binding site in its promoter was stimulated when cotransfected with a RAR $\alpha$ expression vector in the presence of retinoic acid (Figure 4A). Expression of hTAF $\mathrm{II}^{135}$ alone was also able to activate the RAR $\beta$ promoter to the same extent, suggesting that the stimulating effect of exogenous hTAF $_{\text {II }} 135$ maybe mediated through endogenous $\operatorname{RAR} \alpha$. However, co-expression of RAR $\alpha$ and hTAF $_{\mathrm{II}} 135$ resulted in significant stimulation of the RAR $\beta$ promoter. Consistent with this finding is a recent study indicating that transfected $\mathrm{hTAF}_{\mathrm{II}} 135$ is able to potentiate RAR $\alpha$ activation, although a direct interaction between RAR $\alpha$ and $\mathrm{hTAF}_{\mathrm{II}} 135$, as shown here, was not reported (11).

We then tested if the addition of hTAF $_{\text {II }} 135$ affects transcription mediated by $\mathrm{C} / \mathrm{EBP} \alpha$. As seen in Figure 4B, when an obese promoter construct (6) containing a $\mathrm{C} / \mathrm{EBP} \alpha$ binding site was cotransfected with a $\mathrm{C} / \mathrm{EBP} \alpha$ construct into COS cells, there was an almost 50fold increase in promoter activity. When $\mathrm{C} / \mathrm{EBP} \alpha$ was cotransfected with 
increasing concentrations of $\mathrm{hTAF}_{\mathrm{II}^{-}}$ 135 , the promoter activity was reduced dramatically (Figure 4B). This result was corroborated by showing that activation mediated by Gal4- $/ \mathrm{EBP} \alpha$ was also inhibited by $\mathrm{hTAF}_{\mathrm{II}} 135$ overexpression, while activation mediated by Gal4-VP16 was completely unaffected by $\mathrm{hTAF}_{\mathrm{II}} 135$ overexpression (not shown). The specific involvement of hTAF $_{\text {II }} 135$ in this inhibition was further demonstrated by showing that overexpression of another human TAF $\left(\mathrm{hTAF}_{\mathrm{II}} 55\right)$ did not affect $\mathrm{C} / \mathrm{EBP} \alpha$ activation (not shown).

Both RAR $\alpha$ and $\mathrm{C} / \mathrm{EBP} \alpha$ are activators, and yet it is not surprising that overexpression of $\mathrm{hTAF}_{\mathrm{II}} 135$ caused an increase in transcription by RAR $\alpha$ and a decrease in transcription by $\mathrm{C} / \mathrm{EBP} \alpha$. Indeed, depending on the activator, such differences in the effect mediated by the overexpression of $\mathrm{hTAF}_{\mathrm{II}} 135$ have been observed $(9,11,16)$ and may reflect distinct ways in which exogenous $\mathrm{hTAF}_{\mathrm{II}} 135$ either forms or precludes contact of the activator with transcription factor IID (TFIID).

In summary, the RITE assay is a novel approach to identify transcriptional effectors based on their abilities to target specific components of the general transcription machinery. All or part of a general transcription factor is presented to millions of human cDNAencoded peptides expressed by a phage display library. In this study, we have used the RITE assay to screen for peptides that interact with the $\mathrm{C}$ terminus of hTAF $_{\mathrm{II}} 135$ and have identified a novel peptide (RITE-1). Remarkably, 50\% of the 10 different proteins exhibiting homology to the RITE-1 peptide were known transcriptional effectors, while the remaining proteins were known to have other cellular functions. Indeed, we showed that TTAF $_{\text {II }} 135$ could bind to and affect the transcriptional activities of two of these effectors. Importantly, binding to $\mathrm{hTAF}_{\mathrm{II}} 135$ was destroyed by deleting the regions of these effectors, which show homology to the RITE-peptide. We anticipate that the other known transcriptional effectors will also associate with $\mathrm{hTAF}_{\mathrm{II}} 135$. The fact that RITE-1 represents a novel amino acid sequence suggests that it is part of a new effector that is capable of interacting with $\mathrm{hTAF}_{\mathrm{II}} 135$.
By utilizing the sequence information assembled by the human genome project, the RITE assay should make it possible to assign effector functions to new genes. Of practical significance, analysis of different tissue-specific phage display libraries by the RITE assay should lead to the discovery of novel effectors that are important in development and differentiation. Also, the RITE assay may define motifs belonging to certain groups of effectors, which interact with a specific surface of the transcription machinery, thereby lending insights into the regulation of gene expression. Most significantly, the RITE assay represents an invaluable approach in discovering activators and repressors that, when either mutated or abnormally expressed, may be involved in oncogenesis.

\section{ACKNOWLEDGMENTS}

Support for this study from National Institutes of Health grant no. NCI CA 29797 is gratefully acknowledged.

\section{REFERENCES}

1.Altschul, S.F., T.L. Madden, A.A. Schaffer, J. Zhang, Z. Zhang, W. Miller, and D.J. Lipman. 1997. Gapped BLAST and PSI-BLAST: a new generation of protein database search programs. Nucleic Acids Res. 25:3389-3402.

2.Boyer, T.G., M.E. Martin, E. Lees, R.P. Ricciardi, and A.J. Berk. 1999. Mammalian $\mathrm{Srb} /$ mediator complex is targeted by adenovirus E1A protein. Nature 399:276-279.

3.Chien, C.T., P.L. Bartel, R. Sternglanz, and S. Fields. 1991. The two-hybrid system: a method to identify and clone genes for proteins that interact with a protein of interest. Proc. Natl. Acad. Sci. USA 88:9578-9582.

4.Dey, A., S. Minucci, and K. Ozato. 1994. Ligand-dependent occupancy of the retinoic acid receptor beta 2 promoter in vivo. Mol. Cell. Biol. 14:8191-8201.

5.He, L.Z, F. Guidez, C. Tribioli, D. Peruzzi, M. Ruthardt, A. Zelent, and P.P. Pandolfi. 1998. Distinct interactions of PML-RAR alpha and PLZF-RAR alpha with co-repressors determine differential responses to RA in APL. Nat. Genet. 18:126-135

6.Hwang, C.S., S. Mandrup, O.A. MacDougald, D.E. Geiman, and M.D. Lane. 1996. Transcriptional activation of the mouse obese (ob) gene by CCAAT/enhancer binding protein alpha. Proc. Natl. Acad. Sci. USA 93:873-877.

7.Kingston, R.E. 1999. A shared but complex bridge. Nature 399:199-200.

8.Leid, M., P. Kastner, R. Lyons, H. Nakshatri, M. Saunders, T. Zacharewsi, J.Y. Chen, A. Staub et al. 1992. Purification, cloning, and
RXR identity of the HeLa cell factor with which RAR or TR heterodimerizes to bind target sequences efficiently. Cell 68:377-395.

9.Mazzarelli, J.M., G.B Atkins, J.V. Geisberg, and R.P. Ricciardi. 1995. The viral oncoproteins Ad5 E1A, HPV16 E7 and SV40 TAg bind a common region of the TBP-associated factor110. Oncogene 11:1859-1864.

10.Mazzarelli, J.M., G. Menus, I. Davidson, and R.P. Ricciardi. 1997. The transactivation domain of adenovirus E1A interacts with the $\mathrm{C}$ terminus of human $\mathrm{TAF}_{\mathrm{II}} 135$. J. Virol. 71:7978-7983.

11.Mengus, G., M. May, L. Carre, P. Chambon, and I. Davidson. 1997. Human TAF ${ }_{I I} 135$ potentiates transcriptional activation by the AF-2s of the retinoic acid, vitamin D3, and thyroid hormone receptors in mammalian cells. Genes Dev. 11:1381-1395.

12.Nagpal, S., S. Friant, H. Nakshatri, and P. Chambon. 1993. RARs and RXRs: evidence for two autonomous transactivation functions (AF-1 and AF-2) and heterodimerization in vivo. EMBO J. 12:2349-2360.

13.Nerlov, C. and E.B. Ziff. 1994. Three levels of functional interaction determine the activity of CCAAT/enhancer binding protein-alpha on the serum albumin promoter. Genes Dev. 8:350362.

14.Pandey, A. and M. Mann. 2000. Proteomics to study genes and genomes. Nature 405:837846.

15.Rodi, D.J. and L. Makowski. 1999. Phagedisplay technology — finding a needle in a vast molecular haystack. Curr. Opin. Biotechnol. 10:87-93.

16.Saluja, D., M.F. Vassallo, and N. Tanese. 1998. Distinct subdomains of human $\mathrm{TAF}_{\mathrm{II}} 130$ are required for interactions with glutaminerich transcriptional activators. Mol. Cell. Biol. 10:5734-5743.

17.Tanese, N., D. Saluja, M.F. Vassallo, J.L. Chen, and A. Admon. 1996. Molecular cloning and analysis of two subunits of the human TFIID complex: hTAF $_{\text {II }} 130$ and hTAF $_{\text {II }} 100$. Proc. Natl. Acad. Sci. USA 96:13611-13616.

Received 13 April 2000; accepted 18 October 2000.

Address correspondence to:

Dr. Robert P. Ricciardi

University of Pennsylvania

Levy Research Building

Room 221

4010 Locust Street

Philadelphia, PA 19104, USA

e-mail: ricciardi@biochem.dental.upenn.edu 